\section{Ape populations decimated by hunting and Ebola virus}

John Whitfield, London

Chimpanzees and gorillas in West Africa are caught in a pincer movement between hunting and the Ebola virus, researchers have warned. The bushmeat trade is threatening their populations near towns, while Ebola is killing almost every animal in some remote areas.

In a paper on page 611 of this issue, ecologist Peter Walsh of Princeton University, New Jersey, reports that populations of both species have plunged by about half over the past 20 years. Walsh calls for the conservation status of each to be shifted from 'endangered' to 'critically endangered'.

The finding that apes that live near people are in decline because of hunting confirms the long-standing suspicions of conservation workers. But the extent of Ebola's reach in the ape populations has taken experts by surprise. In one remote area where there is little or no hunting, the virus has cut the population by more than $90 \%$ since 1991 .

Everyone agrees that ape populations are under threat, but John Oates of the City University of New York, author of the IUCN's 1996 status survey and action plan for African apes, thinks it would be premature to reclassify them based on this evidence. It is not known whether these declines are repeated across Africa, he says, or how the picture might differ between chimpanzees and gorillas.

Government officials in Gabon, where the survey took place, say that chimpanzees and gorillas are protected there, and that every effort is made to stop illegal hunting. "The population of apes has been quite stable recently," says Pierre Ngavoura, director of water and forests at the Ministry of Water, Forests, Fisheries and the Environment.

Walsh's team counted animals by surveying overnight sleeping nests in many areas, giving a combined population for chimpanzees and gorillas. Gorilla populations in neighbouring Congo - the other remaining population stronghold of these apes in West Africa - are thought to be experiencing similarly high mortality.

The Ebola epidemic may be a result of high ape population density, says Alexander Harcourt, a primatologist at the University of California, Davis. "The normal density of gorillas is about one every two square kilometres," he says. "But in some of these regions there are ten in every square kilometre."

Another possibility, says wildlife-disease expert Andrew Cunningham of the Institute of Zoology in London, is that environmental changes, such as human encroachment on the forest, have brought apes and the virus into closer contact. "The mortality suggests

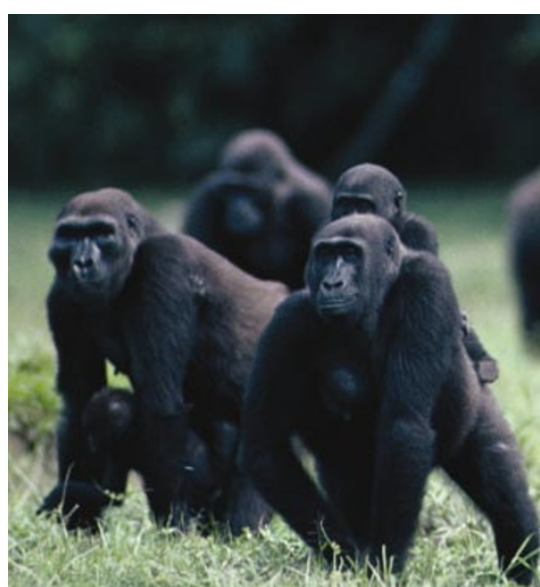

Gorillas will be missed: populations are in decline.

that there has been some trigger leading to the emergence of Ebola as an important cause of ape mortality," he says. The Ebola virus is thought to reside in an unidentified reservoir species - possibly a fruit bat or other small mammal.

Ebola spreads from apes to humans when a hunter kills and eats an animal, or when someone comes into contact with an infected ape corpse. The government in Gabon is seeking to educate its people about the risks of ape hunting, Ngavoura says.

An Ebola outbreak in Gabon killed 50 people between December 2001 and March 2002 , mostly in the remote areas where the ape disease is worst. A current outbreak in Congo has killed 120, according to the World Health Organization.

A further potential hazard is created by commercial poachers who hunt bushmeat for sale in urban Africa, says Richard Ruggiero, African programme officer for the US Fish and Wildlife Service. "It's a very dangerous situation in terms of global health," he says. "I don't think there's a city in the world with a West African immigrant population that doesn't receive ape meat."

Options to control the disease include cutting or digging barriers to quarantine infected populations, moving apes away from where the epidemic is raging, or culling the reservoir species, if it can be identified.

An experimental vaccine has shown good results in monkeys (see Nature 408, 605-609; 2000 ), and may be ready for human trials in a year or two, says Gary Nabel, director of the US National Institutes of Health's Vaccine Research Centre in Bethesda, Maryland. The vaccine might work for apes too, he says. "We'd very much like to use it to help."

www.westerngorilla.org
www.ApeEbolaCrisis.org

\section{French minister breaks diplomatic ice with visit to US}

\section{Geoff Brumfiel, Washington}

It is now ten weeks since US and French presidents George Bush and Jacques Chirac last spoke on the telephone. But as a deep freeze descends on relations between the two former allies, France's science minister, fearless former astronaut Claudie Haigneré, ventured into Washington last week to discuss scientific ties with her US counterparts.

France and the United States are split over the war in Iraq, but Haigneré said on 3 April: "In research and development, we share common objectives." In a two-day trip, she met with top officials from the National Science Foundation, NASA and the Department of Energy, and met John Marburger, President Bush's science adviser, and some members of Congress.

"There was a desire to have a constructive dialogue," Haigneré said of her visit, in which topics discussed ranged from exchange schemes for researchers to international collaboration.

Haigneré met with NASA administrator Sean O'Keefe and discussed the future of the International Space Station. She was told that he hopes that shuttle flights will be resumed by the end of the year. Issues raised at Haigneré's Department of Energy meeting included collaboration on research into alternative energy sources and the construction prospects of ITER, the international magnetic-fusion experiment, which the United States plans to rejoin (see Nature 421,$563 ; 2003$ ).

She also met with three members of the House of Representatives: Dave Weldon (Republican, Florida), Ralph Hall (Democrat, Texas) and Bart Gordon (Democrat, Tennessee).

"In my meeting with the congressmen, the issue of Iraq was raised," she admitted, although she declined to reveal what was said.

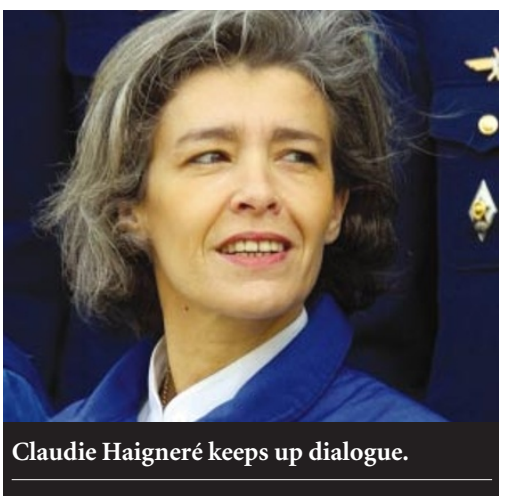

